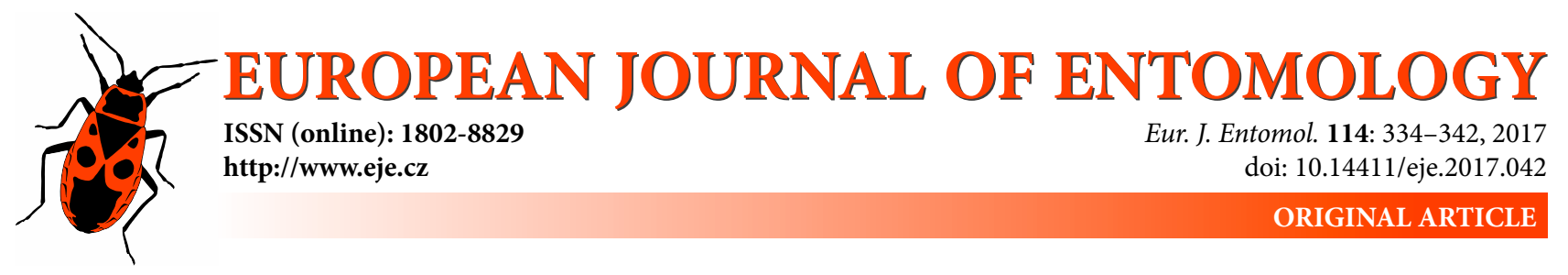

\title{
Response of ground-dwelling harvestman assemblages (Arachnida: Opiliones) to European beech forest canopy cover
}

\author{
L'UdMILA ČERNECKÁ, IVAN MIHÁL and BENJAMIN JARČUŠKA* \\ Institute of Forest Ecology, Slovak Academy of Sciences, L'. Štúra 2, 96053 Zvolen, Slovakia; \\ e-mails: cernecka@savzv.sk, mihal@savzv.sk, benjamin.jarcuska@gmail.com
}

Key words. Opiliones, harvestmen, assemblages, biodiversity, canopy cover, European beech forests

\begin{abstract}
We studied the effects of the overstory canopy cover on ground-dwelling harvestmen communities in European beech forests in the Western Carpathian Mts. We analyzed the differences in species richness, abundance and composition in two tree canopy cover categories (closed and open canopy). Overall, 1765 individuals belonging to 16 species were caught using pitfall traps. Repeated-measures ANOVA revealed that under both closed and open canopies a similar absolute and rarefied species richness and number of individuals (standardized to 100 pitfall trap days) were caught, and that both species richness and abundance were affected by the season (i.e., time of trap replacement); yet the total number of individuals trapped was more than two times greater under the open canopy than under the closed canopy. Despite the subtle differences in the taxonomic composition of the catches under the open and closed canopies revealed by DCA followed by RDA, the composition of ground-dwelling harvestmen assemblages differed under the two canopy covers. The open canopy was more suitable for heliophilic, xerothermic eurytopic harvestmen species typical for open and ecotonal habitats, such as Egaenus convexus (C.L. Koch) and Oligolophus tridens (C.L. Koch) but still suitable for hemihygrophilic Lophopilio palpinalis (Herbst). The closed canopy stands were preferred by shade-tolerant, hygrophilic eurytopic harvestmen species, such as Trogulus sp. Latreille, Dicranolasma scabrum (Herbst) and Platybunus bucephalus (C.L. Koch). Our results highlight the importance of intra-habitat heterogeneity of a harvestmen community.
\end{abstract}

\section{INTRODUCTION}

The extent of tree canopy cover in a forest controls, directly or indirectly, the environmental conditions in the forest understory (Canham et al., 1990). The canopy is the layer with the greatest effect in determining the conditions in habitats in the forest understory (Edgar, 1971). The canopy may act directly through litterfall quality and quantity (Binkley \& Giardina, 1998; Wardle et al., 2004) and indirectly through light availability (Canham et al., 1990), the amount and chemical composition of through fall (Zimmermann et al., 2007) and air and soil temperature (Lemenih et al., 2004). All of these factors affect soil moisture, the rate of decomposition and soil mineralization (Binkley \& Giardina, 1998). Interlinked associations in forest understories lead to changes in forest processes and thus to variability in the properties of the biotic communities inhabiting the forest understory (e.g. Wardle et al., 2004; Smith et al., 2008; Tinya et al., 2009; Barna \& Bosela, 2015; Košulič et al., 2016).

Characteristics of invertebrate communities inhabiting forest ecosystems are also affected by the environmental heterogeneity associated with the canopy of overstory trees. The effects of the species composition of overstory trees and/or their age (Heyborne et al., 2003; Wiezik et al., 2007; Samu et al., 2014; Stašiov et al., 2017), quality and amount of leaf litter and coarse woody debris (Castro \& Wise, 2010; Ranius et al., 2015), canopy closure and/or deer density (Spitzer et al., 2008; Isaia et al., 2015; Košulič et al., 2016) on spatial distribution of invertebrates, species richness, abundance and composition have been documented in many studies.

While the effect of canopy cover is well documented for such organisms as plants, butterflies, orthopterans, beetles and birds, the effect of canopy cover on other groups of organisms, such as e.g. epigeic invertebrates, is less well known (see Spitzer et al., 2008; Zakkak et al., 2014; Isaia et al., 2015; Stephens et al., 2016). Harvestmen are among such under-studied organisms (Curtis \& Machado, 2007). Harvestmen are generalist predators that feed on other small invertebrates and are also scavengers of dead animals, plants (fruits) and fungi (Adams, 1984; Halaj \& Cady, 2000; Hicks et al., 2003; Schaus et al., 2013). Most of the knowledge on the ecology of different species of harvestmen is based on subjective classification of species'

\footnotetext{
* Correspondig author; e-mail: benjamin.jarcuska@gmail.com
} 
affinities with particular environmental conditions (Mitov \& Stoyanov, 2005). Most ecological studies on harvestmen are in agroecosystems (Drummond et al., 2010), because some phalangid species are important predators of pests in fields (Dixon \& McKinlay, 1989; Hilbeck \& Kennedy, 1996), while studies in forest environments are scarce (Bragagnolo et al., 2007; Spitzer et al., 2008; Proud et al., 2012; Merino-Sáinz \& Anadón, 2015; Lira \& DeSouza, 2016).

The most important ecological factors affecting assemblages of harvestmen at large scales are altitude, habitat and moisture regime at the landscape level (Vitosha Mt., Bulgaria; Mitov \& Stoyanov, 2005) and altitude, temperature, human effect and moisture at the country level (Czech Republic; Klimeš, 1997). At a local scale, soil temperature and humidity are the main abiotic factors influencing the structure of communities of harvestmen (Curtis \& Machado, 2007). The effect of the differences in habitats and within-habitat structure on the abundance and distribution of harvestmen is rarely studied (reviewed in Curtis \& Machado, 2007). Microclimatic conditions associated with different types of vegetation could be responsible for differences in the species composition of harvestmen in the north-eastern USA (Edgar, 1971). In Kent, England, Adams (1984) found that the density and compressibility of the litter layer, due to the presence of leaves of different sizes, had an effect on the species composition of harvestman, but that there is a weak effect of litter depth on the richness and density of harvestman in a coniferous stand in Maine, USA (Jennings et al., 1984). Vertical distribution of harvestmen is associated with the forest layer in Michigan broadleaved forests (Edgar, 1971). The importance of the species of trees in the tree canopy for communities of harvestmen is confirmed by Stašiov et al. (2017). Jennings et al. (1984) report a higher abundance and species richness in uncut coniferous forest than in clear cut forests. The temporal pattern and seasonal variation also affects the richness and abundance of harvestmen in forests (Hicks et al., 2003; Urbanovičová et al., 2014).

The aim of this study was to reveal the effect of the overstory canopy cover on assemblages of ground-dwelling harvestmen in European beech (Fagus sylvatica Linnaeus) stands in the Western Carpathian Mts. in Central Europe. We determined the species richness, abundance and composition of assemblages of harvestmen under two different types of canopy cover (closed vs. open canopy) in forest stands. Generally, structurally complex habitats like open canopy forests provide more niches, which are assumed to increase species diversity (Tews et al., 2004). Therefore, we assumed that the species-specific distribution pattern of harvestmen would depend on within-habitat heterogeneity. Taking into account the greater structural complexity of open canopy stands, which provide a greater diversity of suitable habitats, we expect that number of species and the abundance of individuals trapped would be greater in forests with an open canopy than in closed canopy stands. We also focused on seasonal trends in species richness and abundance within the two forests that differed in their extent of canopy cover.

\section{MATERIAL AND METHODS}

\section{Study localities}

This study was done in two managed beech forests in Central Slovakia, in the Western Carpathians. The locality Kováčová $\left(48^{\circ} 38^{\prime} 04.8^{\prime \prime} \mathrm{N}, 19^{\circ} 04^{\prime} 12.4^{\prime \prime} \mathrm{E}\right.$; $475-490 \mathrm{~m}$ a.s.l.) is located in the Kremnické vrchy Mts, which is a moderately warm region with a mean annual temperature of about $6.8^{\circ} \mathrm{C}$ and mean annual precipitation of $780 \mathrm{~mm}$ (Barna \& Schieber, 2011). This site is part of the Long-Term Ecosystem Research (LTER) sites network. The locality Jalná $\left(48^{\circ} 33^{\prime} 05.7^{\prime \prime} \mathrm{N}, 18^{\circ} 56^{\prime} 51.9^{\prime \prime} \mathrm{E}\right.$; $610-620 \mathrm{~m}$ a.s.1.) is located in the Štiavnické vrchy Mts and has a mean annual temperature of $6.2^{\circ} \mathrm{C}$ and mean annual precipitation of $850 \mathrm{~mm}$. The canopy layer in stands in these localities consists mostly of European beech (more than 95\%). Other canopy species are European silver fir (Abies alba Miller), oak [Quercus petraea (Mattuschka) Lieblein] and hornbeam (Carpinus betulus Linnaeus).

The soil type is cambisol at both localities, which has developed on andesite tuff agglomerates, on the western-facing slope at Kováčová and south-west facing slopes at Jalná. The slope inclination at both localities was between $15-20^{\circ}$. Plant associations were Dentario bulbiferae-Fagetum and Carici pilosaeFagetum at Kováčová, and Dentario bulbiferae-Fagetum at Jalná (Vacek et al., 1996).

\section{Characteristics of the stands studied}

At each locality, two plots with a closed canopy and two with an open canopy were selected, i.e., four plots per locality and altogether 8 plots. The closed canopy stands were dense stands ca. $25(\mathrm{n}=1)$ and 100 years old $(\mathrm{n}=3)$; the open canopy stands were stands with plots after shelterwood-cutting with natural regeneration of beech ( 2 and 9 years since final cuts at Jalná, and 3 and 10 years at Kováčová). The closest distance between two plots was at least $100 \mathrm{~m}$. The sizes of the plots with an open canopy were 0.25 ha at Jalná and 0.35 ha at Kováčová.

The altitude, light conditions (canopy openness; \%), cover of forest floor vegetation (up to $10 \mathrm{~cm}$ in height, $10-30 \mathrm{~cm}$, and above $30 \mathrm{~cm}$ in height; \%) and the litter characteristics (ground coverage; \%) were recorded for each pitfall trap at the site. Light conditions, i.e., canopy openness, were determined for each trap using hemispherical images captured $1 \mathrm{~m}$ above the ground by a fish-eye lens (Sigma 4.5 mm F2.8 EX DC, Sigma, Japan). These images were analyzed and the relative proportion of open canopy was estimated using the software Gap Light Analyser 2.0 (GLA) (Frazer et al., 1999). The cover of forest floor vegetation and litter were estimated visually (up to $20 \%$ to the nearest $1 \%$, over $20 \%$ to the nearest $5 \%$ ) in circular plots with a $1 \mathrm{~m}$ diameter around each pitfall trap.

\section{Sampling design and data collection}

Pitfall traps were used to study the activity of harvestmen assemblages. In each stand, eight traps were placed in an $80 \mathrm{~m}$ long line (distance between traps $10 \mathrm{~m}$ ) from March 2012 to September 2013, that is 64 traps in total for ca 18 months. Plastic cups of 0.51 volume, $8.8 \mathrm{~cm}$ in diameter and $13.5 \mathrm{~cm}$ deep were used as traps. The traps were filled up to one-third with a formalin solution (4\%) with a few drops of detergent. The pitfall traps were covered with square wooden covers $(15 \times 15 \mathrm{~cm}) 2 \mathrm{~cm}$ above the trap opening and traps were covered by a wire grids to prevent leaves, debris and small mammals falling into the traps. We emptied the traps 12 and 13 times during the study at Jalná and Kováčová, respectively. When replacing the traps at a locality, individuals from all the traps were pooled into one sample. Harvestmen were identified according to morphological keys (Šilhavý, 1956, 1971; Martens, 1978). Scientific nomenclature of the species was ob- 
tained from Blick \& Komposch (2004). Ecological classification of harvestmen was done according to Stašiov (2004). The majority of the material was preserved in $70 \%$ ethanol and deposited at the Institute of Forest Ecology SAS Zvolen, Slovakia.

\section{Data analysis}

Differences in the environmental characteristics recorded in open and closed canopy stands were assessed using one-way ANOVA.

To characterize the effect of stand cover and season on the number of species of harvestmen (species richness) and abundance, the Repeated Measures ANOVA (RM ANOVA) in software Statistica 7.0 was used (StatSoft, USA). We used one replacement of all traps at a study stand as the basic sample unit (replicates of temporal within-stand variation). For logistical reasons it was not possible to collect material at both localities on the same dates. If there was a difference of more than 14 days between the changing of traps at the two localities, the data obtained were merged with those collected during the subsequent traps replacement. Thus, in the end we acquired data for 11 periods. As the length of the trappings periods varied, number of individuals trapped (abundance) was calculated per 100 trap days for each stand and each trapping period. The number of individuals trapped per 100 days was $\log _{10}$-transformed prior to analysis to obtain a normally distributed error structure and homogenous variance. The rarefied number of species was also calculated after standardizing for sampling effort with the number of individuals set at 20. In RM ANOVA, canopy cover (open or closed) was considered as the between-subject factor and time (the 11 trap changing periods) as the within-subject factor. Mauchly's test was used to check the assumption of sphericity of variance (which was not violated). Rarefied species richness was estimated by individual-based rarefaction using the rarefy function in the package "vegan" (Oksanen et al., 2016) within the R software (R Core Team, 2015).

We assessed the association between species composition of harvestmen assemblages and canopy cover using the ordination techniques in Canoco for Windows 4.5 (Microcomputer Power, USA; ter Braak \& Šmilauer, 2002). First, Detrended Correspondence Analysis (DCA) was performed with detrending by segments, with log-transformed species (the summed number of species) data and down-weighting of rare species. Since the lengths of the gradients were well below 4 (1.625) (Lepš \& Šmilauer, 2003), we used Redundancy Analysis (RDA) in the next step. As the response variable we used data on the annual abundance of harvestmen, with the canopy cover, year of trapping and locality as the categorical explanatory variables. In RDA, scaling was focused on inter-species correlations; species scores were divided by the standard deviation; species data were log-transformed and centred by species, and the Monte-Carlo permutation test with 9999 unrestricted permutations was used in a reduced model. To determine the relative contributions of each variable, alone or in combination with another (interaction), full RDA and partial RDAs (Lepš \& Šmilauer, 2003) were used. The partitioning assessed the pure effect of a variable (pure fraction), thus the percentage variance explained by this variable after all other variables were used as covariables. The joint effect of two or more variables expresses the proportion of variance in which the variables cannot be separated due to their collinearity. Variance explained is shown as percentage of total inertia.

\section{RESULTS}

\section{Characteristics of stands studied}

Open and closed canopy stands (Fig. 1) differ significantly in all variables, litter cover: $\mathrm{F}_{1,62}=70.771, P<0.001$;

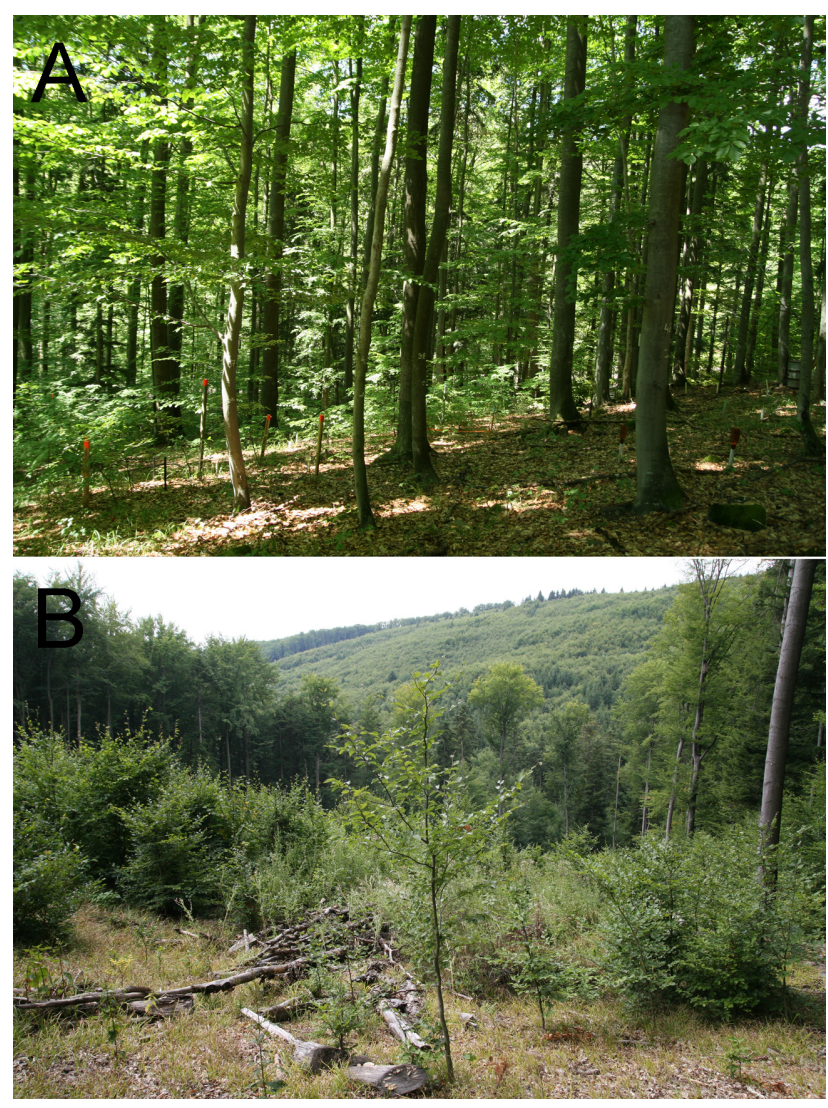

Fig. 1. Beech forest stands with a closed canopy at Jalná $(A)$ and open canopy at Kováčová (B). Photographs by L'. Černecká.

canopy openness: $\mathrm{F}_{1,62}=164.807, P<0.001$; cover of forest floor vegetation up to $10 \mathrm{~cm}$ in height: $\mathrm{F}_{1,62}=89.394$, $P<0.001$; cover of vegetation between 10 to $30 \mathrm{~cm}: \mathrm{F}_{1}$, ${ }_{62}=99.326, P<0.001$; and cover of vegetation above 30 $\mathrm{cm}: \mathrm{F}_{1,62}=100.545, P<0.001$. No differences were found between the altitude of traps in open and closed canopy stands: $\mathrm{F}_{1,62}=0.813, P=0.371$. The mean $[ \pm 1$ standard error (SE)] litter cover in open and closed canopy stands was $38.7 \%( \pm 5.2)$ and $87.3 \%( \pm 2.5)$, and mean canopy openness was $44.9 \%( \pm 3.1)$ and $4.4 \%( \pm 0.3)$, respectively (Table S1). Ground vegetation cover in open canopy stands reached approx. 50\% and in closed canopy stands ca. 5\%.

\section{Harvestmen species richness, abundance and composition of assemblages}

From March 2012 to September 2013, we collected 16 species of harvestmen (1765 individuals) in 64 pitfall traps placed in 8 stands (Table 1). We did not observe a statistically significant effect of canopy cover, alone or in interaction with time, on the number of species (RM ANOVA, absolute: $\mathrm{F}_{1,6}=1.968, P=0.210$; interaction: $\mathrm{F}_{10,60}=0.895$, $P=0.543$; rarefied: $\mathrm{F}_{1,6}<0.001, P=0.995$; interaction: $\left.\mathrm{F}_{10,60}=1.646, P=0.116\right)$ or abundance of harvestmen (RM ANOVA, $\mathrm{F}_{1,6}=3.305, P=0.119$; interaction: $\mathrm{F}_{10,60}$ $=0.907, P=0.532$ ). However, the total number of individuals trapped was more than two times greater under an open canopy than a closed canopy (Table 1). The time of trap replacement had a statistically significant effect on both response variables, species number and abundance 
Table 1. Species list of harvestmen trapped in European beech forest in the Western Carpathians Mts, central Slovakia. The numbers denote total numbers of individuals trapped in 64 pitfall traps placed in 8 closed and open canopy cover stands in 2 localities during 18 months.

\begin{tabular}{|c|c|c|c|c|c|}
\hline \multirow{2}{*}{ Suborder } & \multirow{2}{*}{ Species / Habitat } & \multicolumn{2}{|c|}{ Abundance $(\mathrm{n})$} & \multicolumn{2}{|c|}{ Relative abundance (\%) } \\
\hline & & Closed canopy & Open canopy & Closed canopy & Open canopy \\
\hline Dyspnoi & Dicranolasma scabrum & 64 & 34 & 12.0 & 2.8 \\
\hline Dyspnoi & Nemastoma lugubre & 27 & 95 & 5.1 & 7.7 \\
\hline Dyspnoi & Trogulus nepaeformis & 171 & 158 & 32.1 & 12.8 \\
\hline Dyspnoi & Trogulus tricarinatus & 112 & 96 & 21.0 & 7.8 \\
\hline Dyspnoi & Mitostoma chrysomelas & 1 & 2 & 0.2 & 0.2 \\
\hline Eupnoi & Egaenus convexus & 4 & 80 & 0.8 & 6.5 \\
\hline Eupnoi & Lophopilio palpinalis & 27 & 392 & 5.1 & 31.8 \\
\hline Eupnoi & Lacinius ephippiatus & 46 & 177 & 8.6 & 14.4 \\
\hline Eupnoi & Oligolophus tridens & 10 & 182 & 1.9 & 14.8 \\
\hline Eupnoi & Platybunus bucephalus & 35 & 1 & 6.6 & 0.1 \\
\hline Eupnoi & Platybunus pallidus & 19 & 1 & 3.6 & 0.1 \\
\hline Eupnoi & Phalangium opilio & 0 & 4 & 0.0 & 0.3 \\
\hline Eupnoi & Leiobunum rupestre & 5 & 3 & 0.9 & 0.2 \\
\hline Eupnoi & Zacheus crista & 1 & 1 & 0.2 & 0.1 \\
\hline Eupnoi & Mitopus morio & 10 & 6 & 1.9 & 0.5 \\
\hline Eupnoi & Nelima semproni & 1 & 0 & 0.2 & 0.0 \\
\hline$\sum$ species & & 15 & 15 & & \\
\hline$\overline{\sum \text { individuals }}$ & & 533 & 1232 & 100.0 & 100.0 \\
\hline
\end{tabular}

(RM ANOVA, absolute: $\mathrm{F}_{10,60}=2.845, P=0.006$, rarefied: $\mathrm{F}_{10,60}=3.103, P=0.003$; and $\mathrm{F}_{10,60}=4.639, P<0.001$, respectively). When standardized, the average number of individuals trapped per stand per 100 days was 30.0 (SE $=28.9-31.2$, back-transformed, $\mathrm{n}=88)$ and $8.4 \pm 0.6(\mathrm{SE})$ (rarefied $9.6 \pm 0.6)$ species $(n=8)$. The mean absolute number of species trapped in the trapping periods varied from $2.1 \pm 0.4$ to $5.5 \pm 0.4$ (rarefied from $2.2 \pm 0.5$ to 4.9 $\pm 0.2)(\mathrm{n}=88)$. The lowest number of species was trapped after winter, the largest during the vegetative period, mainly after spring (Fig. 2). A similar pattern was found for the abundance of harvestmen (Fig. 2), and their mean number varied from 5.6 ( $\mathrm{SE}=4.2-7.0)$ to 53.0 (51.7-54.3) (backtransformed data, $\mathrm{n}=88$ ).

The effect of canopy cover on the taxonomic composition of harvestman assemblages differed only slightly between stands with closed and open canopies; however, the number of individuals trapped per species differed in the forests with open and closed canopies (Table 1). Partitioning the variance using RDA and partial RDA analyses revealed that canopy cover can explain differences between harvestman assemblages in forests with closed and open canopies (marginal effect: $r^{2}=23.2, P=0.0125$ ) while neither year of sampling nor locality do (marginal effect: $r^{2}=$ $3.2, P=0.456$, and $r^{2}=10.9, P=0.144$, respectively) (Fig. 3; Table S2).

The ordination diagram (Fig. 3) indicates that an open canopy was more suitable for heliophilic, xerothermic eurytopic species of harvestmen typical of open and ecotonal habitats, such as Egaenus convexus and Oligolophus tridens. The closed canopy stands were preferred by shadetolerant, hygrophilic eurytopic species of harvestmen, such as Trogulus sp., Dicranolasma scabrum and Platybunus bucephalus.
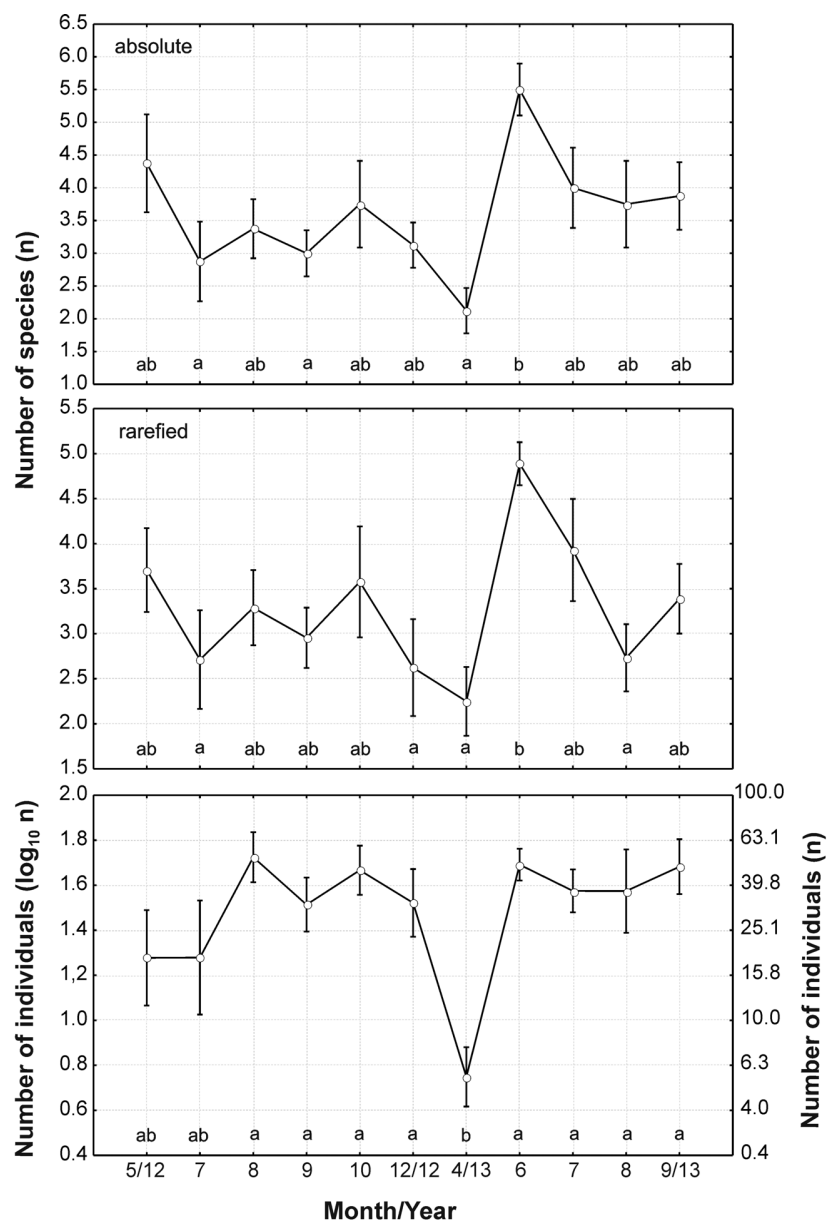

Fig. 2. Mean and standard errors of absolute $(A)$ and rarefied (B) species richness, and the number of individuals standardized to 100 pitfall-trap days $(C)$ trapped in 11 periods at 8 sites. The month and year of the traps' replacement is on the $x$-axis. The catches of traps replaced on the different dates with the same letter do not differ significantly $(P>0.05)$. 


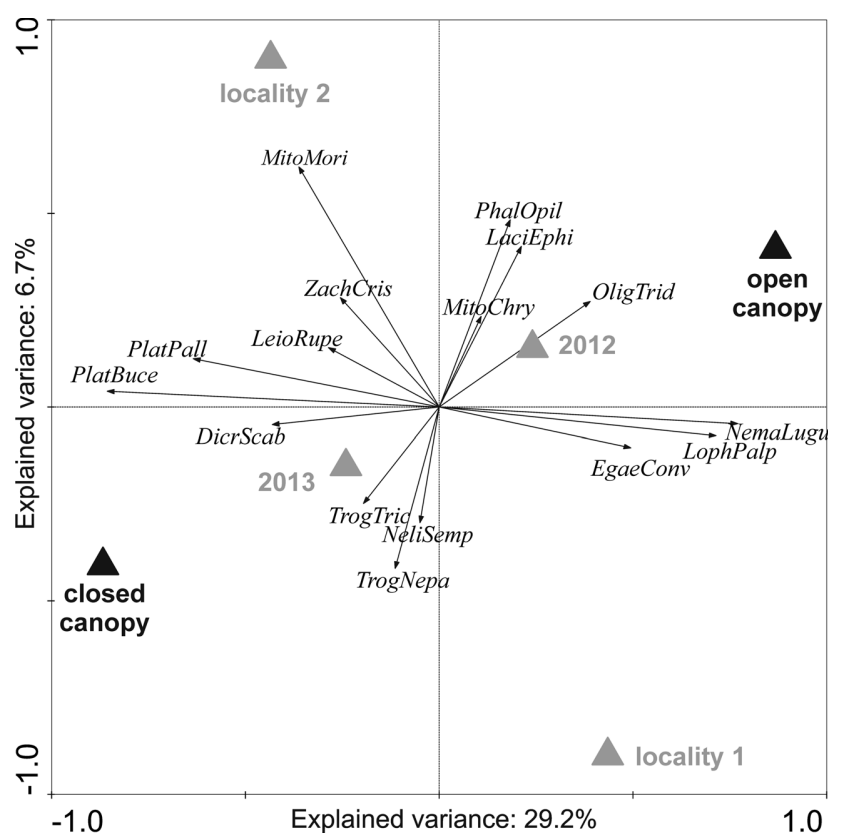

Fig. 3. RDA ordination plot showing the relationship between the composition of the harvestman assemblages and the explanatory variables. Explanatory variables are: canopy cover (closed and open), two localities [Kováčová (1) and Jalná (2)] and year of sampling (2012 and 2013). Centroids of the statistically significant variable, canopy cover, are in bold. Abbreviations for the harvestmen are composed of the first four letters of their genus and species names. Explained variance for each the species data is shown. Species list: Dicranolasma scabrum, Nemastoma lugubre (Müller), Trogulus nepaeformis (Scopoli), Trogulus tricarinatus Linnaeus, Egaenus convexus, Lophopilio palpinalis, Lacinius ephippiatus (C.L. Koch), Oligolophus tridens, Platybunus bucephalus, Platybunus pallidus Šilhavý, Phalangium opilio, Mitostoma chrysomelas (Hermann), Leiobunum rupestre (Herbst), Zacheus crista (Brullé), Mitopus morio, Nelima semproni Szalay.

\section{DISCUSSION}

In this study, we analyzed how a different type of overstory canopy cover in Central Europe beech forests influences communities of harvestmen, in terms of species richness, abundance and species composition. We found that the species richness of harvestmen did not differ in open and closed canopy stands, but the species diversity did. Despite being statistically insignificant $(P=0.119)$, the abundance based on the number of individuals trapped was more than two-times greater in open canopy than in closed canopy forests. Even though the denser, higher and structurally more diverse understory vegetation in the stands with an open canopy might have prevented animals from falling into the pitfall traps (see Paschetta et al., 2013), more specimens were trapped in the plots with an open canopy.

Open canopy stands offer higher structural diversity compared with closed canopy stands. Open canopy stands contain a mosaic of different microhabitats, such as herbaceous and grassy vegetation of various heights, bare ground, shrubs and both young and mature trees. A higher availability of prey, shelter and living space (Denno et al., 2005; Mitov, 2007) and less seasonality in abiotic factors in forest habitats, mainly temperature and humidity (Curtis

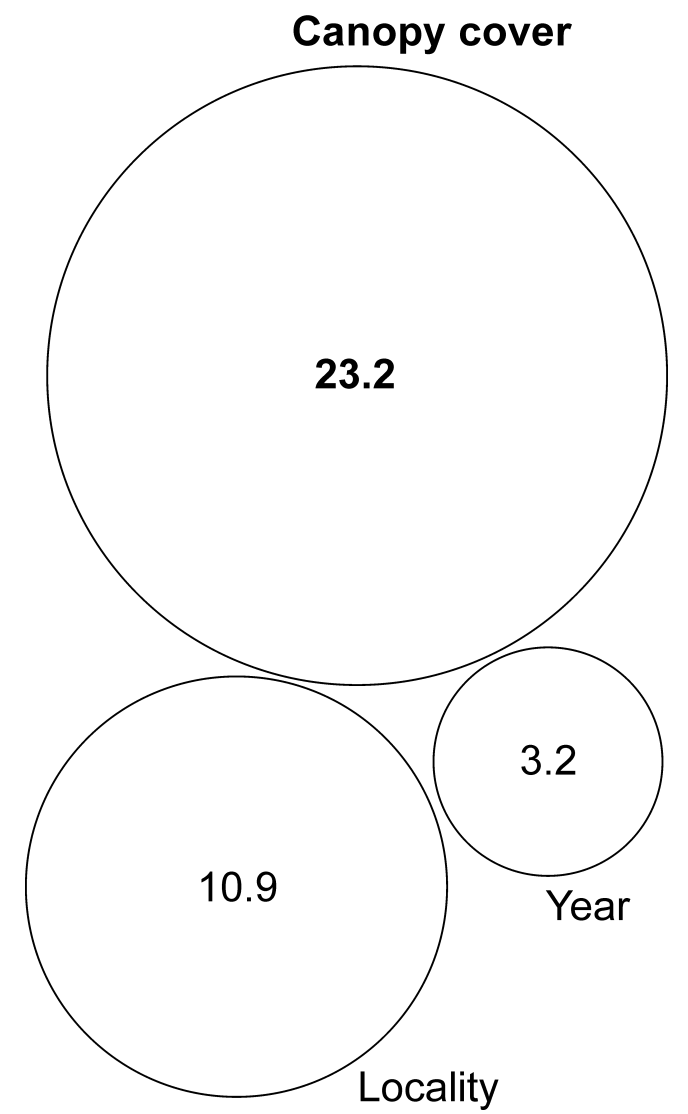

Fig. 4. Partitioning of the variation in harvestman assemblages in beech forests explained by canopy cover, year and locality in the set of RDA models (see Table S2 for the model outputs). The statistically significant variable is in bold. No overlap between the three variables was found.

\& Machado, 2007) are associated with the higher structural diversity in open canopy stands . Therefore, a positive effect of open canopies and therefore stand heterogeneity on species richness and abundance could be expected (Curtis $\&$ Machado, 2007). This assumption has been confirmed for centipedes (Grgič \& Kos, 2005), herbivorous insects (Gittings et al., 2006) and spiders (Oxbrough et al., 2005; Košulič et al., 2016). In a Pannonian thermophilous forest, Spitzer et al. (2008) found a statistically significant greater number of individuals of arachnids, i.e., spiders and harvestmen, in sparse compared to dense stands, while the number of species did not differ between stands with a distinct canopy cover; however, canopy cover did affect species composition. The authors also explained their finding on the abundance of individuals as the positive effect of herbaceous plants and shrubs in stands with a sparse canopy in promoting the hunting of spiders and thus increasing the number of individuals; however, they did not discuss possible reasons for the similar species richness in sparse and dense forest stands. A similar pattern was recorded in our study, though Jennings et al. (1984) in Maine, USA observed the opposite pattern in species richness of harvestmen in their study. They record a greater species richness and abundance of individuals in spruce-fir forest stands than in clear cuts. However, it is unclear whether the observed pattern was the result of harvesting operations car- 
ried out in the clear cut areas (the plots had not yet been colonized) or by spraying the study area with insecticide against spruce budworm (a more detrimental effect on clear cuts compared with a forest understory) (Jennings et al., 1984). On the other hand, the response of carabids was different in the study of Spitzer et al. (2008), in which the greatest species richness and abundance of carabids was recorded in forest stands where prey was most abundant, i.e. in dense stands with deer and in sparse stands without deer.

It is important to note that in this study and some of the abovementioned studies characterize canopy cover as a categorical variable with two levels, while canopy cover is continuous in nature. This simplification of selecting different levels of canopy cover can affect the results. For example, Košulič et al. (2016) studied the effect of canopy cover on spider communities in formerly coppiced oak forests using a gradient of canopy openness ranging from 9 to $98 \%$. They record a hump-shaped association of species richness with the canopy openness; thus, richness was highest in the middle of the canopy openness gradient, i.e. in 55\% canopy openness, suggesting an ecotone effect. In our study, the mean canopy openness under the open canopy was ca. $45 \%$; however, we recorded a similar species richness there as under the closed canopy with ca. $4 \%$ canopy openness (mean $\pm \mathrm{SE}=3.3 \pm 0.27$ and $3.9 \pm$ 0.27 species under closed and open canopy, respectively). On the other hand, similar to our results, the abundance of spiders has a positive linear relationship with canopy openness (Košulič et al., 2016).

Generally, as mentioned above, a highly structured and diverse forest habitat can contain more food, offer more refuges from adverse environmental conditions and predators and thus more living space, and therefore can support a greater abundance of arthropods (Denno et al., 2005; Košulič et al., 2016); however, contradictory results are reported (Tews et al., 2004). The pattern of association between habitat and species diversity depends on the taxonomic group, the structure of the vegetation and the spatial scale. The species diversity of an animal group is associated with structural characteristics occurring at a specific scale, which reflect important habitat requirements of the animal group in terms of protection against predators, foraging activity and reproduction. For example, forest gaps can increase habitat heterogeneity for butterflies and birds but fragment the habitats of ground beetles (Tews et al., 2004). Diversity patterns of bark-dwelling spiders are scale dependent in both vertical and horizontal space even at the tree scale, driven by local dynamics such as niche availability and species interactions (Larrivée \& Buddle, 2010).

Greater species richness and abundance of harvestmen were recorded in this study during the vegetative period, species richness mainly after spring and abundance evenly during the vegetative period (Fig. 2). The same pattern of seasonal activity of harvestmen is reported in wind thrown Norway spruce forests in the High Tatras (Urbanovičová et al., 2014). However, Urbanovičová et al. (2014) report significant differentiation associated with season and stand structure, with a greater abundance in summer in unharvested reference stands than in wind thrown plots harvested two years previously, but only subtle differences during winter. Canopy tree can affect the seasonality in the diversity and abundance of harvestmen; for example, they differ in abundance in Scots pine and lodge pole pine habitats (Hicks et al., 2003).

The taxonomic composition of assemblages in open and closed canopy plots differed only by one species $(Z$. crista); however, the number of individuals per species differed in the two types of plots (Table 1). Most of the species of harvestmen recorded in both plots generally prefer a humid habitat, mostly in forests. We recorded 16 of the 27 species of harvestmen known to occur in beech forests in Slovakia (Stašiov, 2004). Five species (Dicranolasma scabrum, Nemastoma lugubre, Mitostoma chrysomelas, Trogulus nepaeformis, Trogulus tricarinatus) belonging to the suborder Dyspnoi and superfamily Troguloidea (Schönhofer, 2013). These soil-dwelling harvestmen are short legged and are more likely to fall into pitfall traps then long-legged harvestmen. Four species (Leiobunum rupestre, Mitopus morio, Nelima semproni, Phalangium opilio) belonging to the suborder Eupnoi are long-legged species so they were less likely to fall into the pitfall traps. In this study they comprised only $2 \%$ of the individuals trapped. L. rupestre, M. morio, N. semproni, P. opilio and Platybunus bucephalus rest on leaves or trunks of shrubs or trees but forage on litter at night, which should not affect the number of individuals falling into pitfall traps. The most abundant species in this study was L. palpinalis $(25 \%$ of the individuals trapped). The species L. palpinalis is primarily hemi-hygrophilic, preferring shaded habitats in forests but can occur on humid open canopy areas, such as wetlands (Martens, 1978; Stašiov, 2004). In this study L. palpinalis and L. epphippiatus were more abundant in open canopy stands; this could be due to better environmental conditions for both species, which use moss and the upper layers of humid soil for resting or feeding. L. palpinalis sometimes can be found on shaded vegetation (Wijnhoven, 2009). In closed canopy stands the soil surface was covered with compact beech leaf litter mostly without moss and herbaceous plants, so these environmental conditions were not suitable for them. In this study the species Oligolophus tridens preferred open canopy stands, and is reported living on the edges of coniferous and deciduous forests, marshy ground, gardens and open wet places from August till December (Bliss, 1982; Wijnhoven, 2009). We confirmed this distribution and temporal pattern (data not shown). The species Egaenus convexus was found only in open canopy stands at both localities. This species is thermophilic and the centre of its distribution is the Balkan Peninsula (Martens, 1978). Dicranolasma scabrum prefers leaf litter in deciduous forests (Stašiov, 2004) and T. nepaeformis is strongly associated with humid forests (Komposch \& Gruber, 2004).

Only minor differences in the taxonomic composition of ground-dwelling harvestman assemblages were recorded in the open and closed beech forest canopy plots in this 
study, which indicates that microsites with similar environmental conditions (i.e. providing similar niches) occur in the two canopy-cover categories, but with a lower incidence in the closed canopy plots, which may account for the pattern in diversity recorded in this study. Also, the occurrence of various ubiquitous and euryoecious species (Oligolophus tridens, Lacinius eppihiatus and Mitopus morio), which mostly show no preference for any specific vegetation structure in forest stands may be responsible for the pattern of species richness and composition recorded in this study. Edgar (1971) offers a similar explanation for various species of harvestmen in different types of vegetation in floodplain forests in Michigan, USA. A closed canopy beech forest matrix can limit the colonization by open-habitat species of small plots with an open canopy (cf. Stašiov et al., 2017). Moreover, such surrounded plots generally have only a short-term existence due to forest succession, which does not allow species of harvestmen like Phalangium opilio, Mitostoma chrysomelas and other typical species of open habitats to colonise these open canopy plots, or for their long-term existence.

In conclusion, our results highlight the importance of considering not only inter-habitat variability in assessing patterns in species richness, abundance and assemblage composition but also intra-habitat variability. The canopy cover of European beech forest affects the abundance of particular species in ground-dwelling assemblages more than their taxonomic composition, and the total abundance of individuals trapped. Our findings support the importance of habitat heterogeneity for assemblage composition in this understudied group of epigeic organisms, the harvestmen.

ACKNOWLEDGEMENTS. We thank S. Korenko and two anonymous referees for their comments on the manuscript, and D. McLean (Prešov) for linguistic revision of the manuscript. The study was financially supported by the Science Grant Agency of the Ministry of Education of the Slovak Republic and the Slovak Academy of Sciences, grant VEGA No. 2/0012/17 and 2/0061/15.

DISCLOSURE. The authors declare that they have no conflict of interest.

\section{REFERENCES}

ADAMS J. 1984: The habitat and feeding ecology of woodland harvestmen (Opiliones) in England. - Oikos 42: 361-370.

Barna M. \& Bosela M. 2015: Tree species diversity change in natural regeneration of a beech forest under different management. - For. Ecol. Manag. 342: 93-102.

BARNA M. \& SChIEBer B. 2011: Climate response to forest management in beech stands. - Folia Oecol. 38: 8-16.

BinkLey D.A.N. \& Giardina C. 1998: Why do tree species affect soils? The warp and woof of tree-soil interactions. - Biogeochemistry 42: 89-106.

Buick T. \& Комтоsсн C. 2004: Checkliste der Weberknechte Mittel-und Nordeuropas. Checklist of the Harvestmen of Central and Northern Europe (Arachnida: Opiliones). Version 27 December 2004. URL: http://www.AraGes.de/checklist. html\#2004 Opiliones

Bragagnolo C., Nogueira A.A., Pinto-Da-Rocha R. \& Pardini R. 2007: Harvestmen in an Atlantic forest fragmented land- scape: evaluating assemblage response to habitat quality and quantity. - Biol. Conserv. 139: 389-400.

Canham C.D., Denslow J.S., Platt W.J., Runkle J.R., Spies T.A. \& White P.S. 1990: Light regimes beneath closed canopies and tree-fall gaps in temperate and tropical forests. - Can. J. For. Res. 20: 620-631.

CAstro A. \& Wise D.H. 2010: Influence of fallen coarse woody debris on the diversity and community structure of forestfloor spiders (Arachnida: Araneae). - For. Ecol. Manag. 260: 2088-2101.

Curtis D.J. \& Machado G. 2007: Ecology. In Pinto-da-Rocha R., Machado G. \& Giribet G. (eds): Harvestmen. The Biology of Opiliones. Harvard University Press, Cambridge, MA, pp. 280-308.

Denno R.F., Finke D.L. \& Langellotto G.A. 2005: Direct and indirect effects of vegetation structure and habitat complexity on predator-prey and predator-predator interactions. In Barbosa P. \& Castellanos I. (eds): Ecology of Predator-Prey Interactions. Oxford University Press, pp. 211-239.

Dixon P.L. \& McKinlay R.G. 1989: Aphid predation by harvestmen in potato fields in Scotland. - J. Arachnol. 17: 253-255.

Drummond F., Collins J.A., Choate B., Woodman D., Jennings J.T., Forsythe H.Y. \& CoKendolpher J. 2010: Harvestman (Opiliones) fauna associated with Maine lowbush blueberry fields in the major production areas of Washington and Hancock counties. - Environ. Entomol. 39: 1428-1440.

EdGar A.L. 1971: Studies on the Biology and Ecology of Michigan Phalangida (Opiliones). Miscellaneous Publications no. 144. Museum of Zoology, University of Michigan, Ann Arbor, $68 \mathrm{pp}$.

Frazer G.W., Canham C.D. \& Lertzman K.P. 1999: Gap Light Analyzer (GLA). Ver. 2.0. Imaging Software to Extract Canopy Structure and Gap Light Transmission Indices from True-Color Fisheye Potographs. Users' Manual and Program Documentation. Simon Fraser University, Burnaby, Institute of Ecosystem Studies, Millbrook, $80 \mathrm{pp}$.

Gittings T., O’Halloran J., Kelly T. \& Gille P.S. 2006: The contribution of open spaces to the maintenance of hoverfly (Diptera, Syrphidae) biodiversity in Irish plantation forests. For. Ecol. Manag. 237: 290-300.

GRGIČ T. \& Kos I. 2005: Influence of forest development phase on centipede diversity in managed beech forests in Slovenia. - Biodiv. Conserv. 14: 1841-1862.

HAlAJ J. \& CADY A.B. 2000: Diet composition and significance of earthworms as food of harvestmen (Arachnida: Opiliones). Am. Midl. Nat. 143: 487-491.

Heyborne W.H., Miller J.C. \& Parsons G.L. 2003: Ground dwelling beetles and forest vegetation change over a 17 -yearperiod, in western Oregon, USA. - For. Ecol. Manag. 179: 123-133.

Hicks B., McKenzie F., Cosens D. \& Watt A.D. 2003: Harvestmen abundance and diversity within lodgepole and Scots pine plantations of Scotland and their impact on pine beauty moth populations. - For. Ecol. Manag. 182: 355-361.

Hilbeck A. \& Kennedy G.G. 1996: Predators feeding on the Colorado potato beetle in insecticide-free plots and insecticidetreated commercial potato fields in Eastern North Carolina. Biol. Contr. 6: 273-282.

isaia M., Paschetta M., Gobbi M., Zapparoli M., Chiarle A. \& TAGLIANTI A.V. 2015: Stand maturity affects positively grounddwelling arthropods in a protected beech forest. - Ann. For. Sci. 72: 415-424.

JenNings D.T., Houseweart M.W. \& CoKendolpher J.C. 1984: Phalangids (Arachnida: Opiliones) associated with strip 
clearcut and dense spruce-fir forests of Maine. - Environ. Entomol. 13: 1306-1311.

KLIMEš L. 1997: Harvestman (phalangida) assemblages in the Czech Republic. - Acta Soc. Zool. Bohem. 61: 297-309.

Komposch G. \& Gruber J. 2004: Die Weberknechte Österreichs (Arachnida, Opiliones). — Denisia 12: 485-534.

Košulič O., Michalko R. \& Hula V. 2016: Impact of canopy openness on spider communities: implications for conservation management of formerly coppiced oak forests. - PLOS ONE 11: e0128585, $18 \mathrm{pp}$.

LARrivÉe M. \& Buddle C.M. 2010: Scale dependence of tree trunk spider diversity patterns in vertical and horizontal space. - Ecoscience 17: 400-410.

Lemenih M., Gidyelew T. \& Teketay D. 2004: Effects of canopy cover and understory environment of tree plantations on richness, density and size of colonizing woody species in southern Ethiopia. - For. Ecol. Manag. 194: 1-10.

LePŠ J. \& ŠMILAuER P. 2003: Multivariate Analysis of Ecological Data Using Canoco. Cambridge University Press, Cambridge, $283 \mathrm{pp}$.

LiRA A.F.A. \& DeSouza A.M. 2016: Microhabitat use of harvestmen (Arachnida: Opiliones) assemblage in the highland Brazilian Atlantic rainforest. - Can. J. Zool. 94: 323-327.

Martens J. 1978: Weberknechte, Opiliones - Spinnentiere, Arachnida. In Senglaub K., Hannemann H.J. \& Shumann H. (eds): Die Tierwelt Deutschlands, 64. Teil. Fischer, Jena, 464 pp.

MERINO-SÁINZ I. \& ANADÓN A. 2015: Local distribution patterns of harvestmen (Arachnida: Opiliones) in a Northern temperate Biosphere Reserve landscape: influence of orientation and soil richness. - Belg. J. Zool. 145: 3-16.

Mitov P.G. 2007: Spatial niches of Opiliones (Arachnida) from Vitosha Mountains, Bulgaria. In Fet V. \& Popov A. (eds): Biogeography and Ecology of Bulgaria. Springer, Dordrecht, pp. 423-446.

Mitov P.G. \& Stoyanov I.L. 2005: Ecological profiles of harvestmen (Arachnida, Opiliones) from Vitosha Mountain (Bulgaria): a mixed modelling approach using gams. - J. Arachnol. 33: $256-268$.

Oksanen J., Blanchet F.G., Kindt R., Legendre P., Minchin P.R., O’Hara R.B., Simpson G.L., Solymos P., Stevens M.H.H. \& WAGNER H. 2016: Package 'vegan'. Community Ecology Package, Version, 2.3-4. URL: https://cran.r-project.org/web/packages/vegan/index.html (last accessed 28 Feb. 2016).

Oxbrough A.G., Gittings T., O’Halloran J., Giller P.S. \& SMith G.F. 2005: Structural indicators of spider communities across the forest plantation cycle. - For. Ecol. Manag. 212: 171-183.

Paschetta M., La Morgia V., Masante D., Negro M., Rolando A. \& ISAIA M. 2013: Grazing history influences biodiversity: a case study on ground-dwelling arachnids (Arachnida: Araneae, Opiliones) in the Natural Park of Alpi Marittime (NW Italy). J. Insect Conserv. 17: 339-356.

Proud D.N., Felgenhauer B.E., Townsend V.R., Osula D.O., Gilmore W.O., Napier Z.L. \& Van Zandt P.A. 2012: Diversity and habitat use of Neotropical harvestmen (Arachnida: Opiliones) in a Costa Rican rainforest. — ISRN Zoology 2012: 549765, $16 \mathrm{pp}$.

Ranius T., Johansson V., Schroeder M. \& Caruso A. 2015: Relative importance of habitat characteristics at multiple spatial scales for wood-dependent beetles in boreal forest. - Landsc. Ecol. 30: 1931-1942.

SAmu F., Lengyel G., Szita É., Bidló A. \& Ódor P. 2014: The effect of forest stand characteristics on spider diversity and species composition in deciduous-coniferous mixed forests. $-J$. Arachnol. 42: 135-141.
Schaus H.M., Townsed V.R. \& ILLINIK J.J. 2013: Food choice of the Neotropical harvestman Erginulus clavotibialis (Opiliones: Laniatores: Cosmetidae). - J. Arachnol. 41: 219-221.

SCHÖNHOFER A.L. 2013: A taxonomic catalogue of the Dyspnoi Hansen and Sørensen, 1904 (Arachnida: Opiliones). Zootaxa 3679: 1-68.

ŠILhavÝ V. 1956: Opilionidea. Fauna ČSR, Vol. 7. Czechoslovak Academy of Sciences Publ., Praha, 274 pp. [in Czech].

ŠILhaVÝ V. 1971: Opilionidea. In Daniel M. \& Černý V. (eds): The Keys of Animals of the ČSSR IV. Academia, Praha, pp. 35-50 [in Czech].

Smith G.F., Gittings T., Wilson M., French L., Oxbrough A. \& DonoghuE S. 2008: Identifying practical indicators of biodiversity for stand-level management of plantation forests. - Biodiv. Conserv. 17: 991-1015.

STAŠIov S. 2004: [Harvestmen (Opiliones) of Slovakia. Scientific Studies 3/2004/A.] Publishing house of the Technical University in Zvolen, $119 \mathrm{pp}$. [in Slovak].

Stašıov S., Michalková E., LukáčiK I. \& ČIllak M. 2017: Harvestmen (Opiliones) communities in an arboretum: Influence of tree species. - Biologia 72: 184-193.

Stephens S.S., Bosu P.P. \& Wagner M.R. 2016: Effect of overstory tree species diversity and composition on ground foraging ants (Hymenoptera: Formicidae) in timber plantations in Ghana. - Int. J. Biodiv. Sci. Ecosyst. Serv. Manag. 12: 96-107. Spitzer L., Konvicka M., Benes J., Tropek R., Tuf I.H. \& Tufova J. 2008: Does closure of traditionally managed open woodlands threaten epigeic invertebrates? Effects of coppicing and high deer densities. - Biol. Conserv. 141: 827-837.

R Core Team 2015: $R$ : A Language and Environment for Statistical Computing. R Foundation for Statistical Computing, Vienna. URL: https://www.R-project.org/.

TER BraAk C.J.F. \& Šmilauer P. 2002: CANOCO Reference Manual and CanoDraw for Windows. User's Guide. Software for Canonical Community Ordination, Ver. 4.5. Microcomputer Power, Ithaca, NY, $500 \mathrm{pp}$.

Tews J., Brose U., Grimm V., Tielbörger K., Wichmann M.C., SChWAGER M. \& Jeltsch F. 2004: Animal species diversity driven by habitat heterogeneity/diversity: the importance of keystone structures. - J. Biogeogr. 31: 79-92.

Tinya F., Márialigeti S., Király I., Németh B. \& Odor P. 2009: The effect of light conditions on herbs, bryophytes and seedlings of temperate mixed forests in Örség, Western Hungary. - Plant Ecol. 204: 69-81.

Urbanovičová V., Miklisova D., Mock A. \& Kováč L'. 2014: Activity of epigeic arthropods in differently managed windthrown forest stands in the High Tatra Mts. - N.-W. J. Zool. 10: 337345.

VACEK S., Lepš J., ŠTEFAnČíK I. \& CiCÁK A. 1996: Precision of visual estimates of tree defoliation. - Lesnictví 42: 49-53 [in Czech].

Wardle D.A., Bardgett R.D., Klironomos J.N., Setälä H., Van Der Putten W.H. \& Wall D.H. 2004: Ecological linkages between aboveground and belowground biota. - Science 304: $1629-1633$.

WIEZIK M., SvitoK M. \& DovČIAK M. 2007: Conifer introductions decrease richness and alter composition of litter-dwelling beetles (Coleoptera) in Carpathian oak forests. - For. Ecol. Manag. 247: 61-71.

WisNHOVEN H. 2009: De Nederlandse hooiwagens (Opiliones). Entomol. Tabell. 3: 1-118.

Zakkak S., Chatzaki M., Karamalis N. \& Kati V. 2014: Spiders in the context of agricultural land abandonment in Greek Mountains: species responses, community structure and the 
need to preserve traditional agricultural landscapes. - J. Insect Conserv. 18: 599-611.

Zimmermann A., Wilcke W. \& Elsenbeer H. 2007: Spatial and temporal patterns of throughfall quantity and quality in a tropical montane forest in Ecuador. - J. Hydrol. 343: 80-96.

Received November 16, 2016; revised and accepted July 5, 2017 Published online July 24, 2017

Table S1. Summary statistics of the environmental variables recorded at open and closed canopy stands ( $n=32$ traps per canopy cover level).

\begin{tabular}{|c|c|c|c|c|c|c|c|c|}
\hline Variable & Unit & $\begin{array}{c}\text { Canopy } \\
\text { cover }\end{array}$ & Mean & Median & SD & Minimum & Maximum & Coef. of var. \\
\hline \multirow{2}{*}{ Litter cover } & \multirow{2}{*}{$\%$} & Open & 38.8 & 40.0 & 29.3 & 0.0 & 85.0 & 75.7 \\
\hline & & Closed & 87.3 & 92.5 & 14.4 & 50.0 & 100.0 & 16.4 \\
\hline \multirow{2}{*}{ Canopy openess } & \multirow{2}{*}{$\%$} & Open & 44.9 & 45.7 & 17.8 & 13.8 & 69.4 & 23.6 \\
\hline & & Closed & 4.4 & 3.9 & 1.6 & 2.1 & 8.8 & 36.5 \\
\hline \multirow{2}{*}{$\begin{array}{l}\text { Cover of forest floor vegetation } \\
\text { up to } 10 \mathrm{~cm} \text { of height }\end{array}$} & \multirow{2}{*}{$\%$} & Open & 36.9 & 30.0 & 21.1 & 5.0 & 70.0 & 57.1 \\
\hline & & Closed & 1.5 & 1.0 & 2.1 & 0.0 & 10.0 & 135.6 \\
\hline \multirow{2}{*}{$\begin{array}{l}\text { Cover of forest floor vegetation } \\
\text { between } 10-30 \mathrm{~cm}\end{array}$} & \multirow{2}{*}{$\%$} & Open & 55.3 & 50.0 & 21.6 & 10.0 & 90.0 & 39.0 \\
\hline & & Closed & 7.1 & 1.0 & 16.9 & 0.0 & 80.0 & 238.3 \\
\hline \multirow{2}{*}{$\begin{array}{l}\text { Cover of forest floor vegetation } \\
\text { above } 30 \mathrm{~cm}\end{array}$} & \multirow{2}{*}{$\%$} & Open & 48.5 & 45.0 & 26.4 & 1.0 & 90.0 & 54.6 \\
\hline & & Closed & 1.2 & 0.0 & 3.6 & 0.0 & 20.0 & 304.5 \\
\hline \multirow{2}{*}{ Altitude of the trap } & $\mathrm{m}$ & Open & 576.7 & 531.0 & 113.0 & 465.0 & 768.0 & 19.6 \\
\hline & a.s.l. & Closed & 556.1 & 543.0 & 61.8 & 487.0 & 630.0 & 10.9 \\
\hline
\end{tabular}

Table S2. Significance of RDA models and variation partitioning among canopy cover, year and locality explaining harvestman assemblages in beech forests.

\begin{tabular}{|c|c|c|c|}
\hline Variable(s) & Covariable(s) & Explained variability (\%) & $\mathrm{P}$ \\
\hline Canopy cover & None & 23.2 & 0.013 \\
\hline Year & None & 3.2 & 0.456 \\
\hline Locality & None & 10.9 & 0.144 \\
\hline Canopy cover & Year + Locality & 23.2 & 0.015 \\
\hline Year & Canopy cover + Locality & 3.2 & 0.662 \\
\hline Locality & Canopy cover + Year & 10.9 & 0.090 \\
\hline Canopy cover + Year & Locality & 26.4 & 0.042 \\
\hline Canopy cover + Locality & Year & 34.1 & 0.011 \\
\hline Year + Locality & Canopy cover & 3.2 & 0.727 \\
\hline Canopy cover + Year + Locality & None & 37.3 & 0.028 \\
\hline
\end{tabular}

